\title{
WHATSAPP AS AN ONLINE LEARNING TOOL FOR LIBRARY SCIENCE STUDENTS
}

\author{
Ramadayanti ${ }^{1}$ \\ ${ }^{1}$ Universitas UIN Alauddin Makassar \\ Correspondence email: ramadayantiniezt@gmail.com
}

\begin{abstract}
Whats $A p p$ as one of the most influential social media and is widely used by Indonesia. Students in Indonesia in the digital era are currently using gadgets in their daily activities. However, many students have use social media applications, especially Whats App, only for social media, not improve digital literacy skills. The purposes of the study were to determine: 1) the role of in online learning Process, and 2) the benefits of (Whats App) in online learning process for Library Sciences students at UIN Alauddin Makassar. The data were gathered through listening, taking notes, online interviews, literature review. The results of this study showed that 1) the role of Whats $A p p$ really helps students in learning process,and 2). the benefits of Whats $A p p$ as digital literacy mediain distance learning (PJJ) may use voice note or video call feature, sharing material, an so on. Whats App makes it easy to have conversations through the chat, it can copy, delete, or forward messages. Images that are sent can be forwarded. In addition, students can also send voice messages and share the their location.
\end{abstract}

Keywords : Social Media; Learning; WhatsApp

\begin{abstract}
Abstrak
Whats App sebagai salah satu media sosial paling berpengaruh dan banyak digunakan oleh masyarakat di Indonesia. Para mahasiswa di Indonesia pada era digital saat ini sudah menggunakan gawai dalam aktivitas keseharian mereka baik di kampus maupun di luar kampus. Namun, sebagian besar pelajar menggunakan aplikasi media sosial, khususnya WhatsApp, hanya untuk bermedia sosial saja, padahal di dalam aplikasi tersebut, terdapat manfaat yang bisa meningkatkan kemampuan literasi digital. Tujuan dari penelitian ini adalah untuk mengetahui: 1) Peran Media Sosial (Whats App) Dalam Proses Belajar Online (Daring) Di Kelas Ap.3/4 Jurusan Ilmu Perpustakaan Uin Alauddin Makassar dan 2) manfaat Media Sosial (WhatsApp) Dalam Proses Belajar Online (Daring) Di Kelas Ap.3/4 Jurusan Ilmu Perpustakaan Uin Alauddin Makassar.Metode yang digunakan pada penelitian ini adalah simak, catat, dan wawancara online,kajian pustaka. Penelitian ini adalah penelitian deskriptif kualitatif. Hasil penelitian ini yaitu,1).peran media sosial Whats App sangat membantu mahasiswa dalam proses belajar secara online (Daring) dan 2). Manfaat media sosial Whats App
\end{abstract}


Whats App sebagai Media Literasi digital, Pembelajaran Jarak Jauh (PJJ) yang menggunakan fitur voice note atau video call, Berbagi materi melalui Whats App Story. Whats $A p p$ memudahkan dalam percakapan melalui menu chat, bisa meng-copy, men-delete, atau memforward pesan. Gambar yang terkirim bisa di-forward, Selain itu juga dapat mengirim pesan suara maupun share lokasi keberadaan pengguna.

Kata kunci: Mahasiswa; Media Sosial; WhatsApp

\section{Pendahuluan}

Di tengah masa pandemi covid 19 yang saat ini melanda seluruh dunia termasuk di negara Indonesia. Virus covid19 ini sangat meresahkan dan membahayakan bagi manusia dan ini dianggap suatu bencana darurat nasional yang harus segera cepat diatasi. Dampak dari virus covid19 ini adalah banyak Negara memutuskan untuk menutup sekolah,perguruan tinggi dan universitas.Penyebaran covid19 ini pada awalnya hanya berdampak pada bidang ekonomi tetapi kini sudah berdampak pada dunia pendidikan. Kebijakan yang diambil oleh banyak Negara termasuk Indonesia dengan meliburkan seluruh aktifitas pendidikan, membuat pemerintah dan lembaga terkait harus menghadirkan alternatif proses pendidikan bagi peserta didik maupun mahasiswa yang tidak bisa melaksanakan proses pendidikan pada lembaga pendidikan.

Bersama dengan perkembangan zaman, maka proses belajar mengajar di sekolah dan bangku kuliah turut mengalami perubahan. Dalam konteks TIK (Teknologi Informasi dan Komunikasi), penetrasi gadget yang begitu deras telah mengubah paradigma pendidikan menjadi technology-based. Di era sekarang ini, telah lahir generasi digital native, yang sudah sangat familiar terhadap TIK dari usia sangat dini. Walaupun tentunya masih dibatasi terhadap aplikasi pendidikan usia dini, Hal ini yang mengakibatkan bagaimana generasi digital menyerap informasi, dalam rangka proses belajar,sudah sangat berbeda dengan generasi pendahulu mereka.Sebagai contoh, generasi digital sudah terbiasa mencari informasi pada Google dan Wikipedia untuk membantu menyelesaikan pekerjaan rumah mereka. Akan tetapi, ada satu tools yang berbeda dengan yang lain. Tools ini dapat mendiseminasi informasi dalam jumlah sangat besar, bahkan membagikannya ke seluruh dunia dengan cepat. Tools ini adalah 'senjata pamungkas' bagi generasi digital untuk mendidik diri mereka sendiri. Ia adalah media sosial (Medsos).

Media sosial dalam dunia pendidikan merupakan proses penggunaan media dalam sistem dan metode belajar mengajar yang mengutamakan sebuah interaksi sosial di dalamnya. Media sosial dalam dunia pendidikan telah menjadi sebuah bentuk timbal balik yang hasilnya baik positif maupun negatif masih terus berkembang secara luas. Di zaman era globalisasi ini hampir seluruh aspek kehidupan mengalami perubahan yang pesat. Perkembangan ilmu pengetahuan dan teknologi (IPTEK) sangat berpengaruh terhadap setiap aspek kehidupan manusia mulai dari 
gaya hidup,interaksi secara khusus dalam dunia pendidikan,hubungan sosial dan lain-lain. Perkembangan teknologi membuat serangkaian manusia lebih senang akan hal-hal yang berbeda ataupun unik sehingga manusia terkadang lebih senang akan interaksinya di dunia maya. Perkembangan teknologi yang pesat menumbuhkan inovasi-inovasi baru yang baru yang lebih menggiurkan manusia. Kita sebagai umat yang memilki akal budi dan pikiran,kita harus mampu memilahmilih mana yang bermanfaat bagi kita dan sesuia akan kebutuhan kita,tidak membuat kita menjadi jatuh kedalam hal-hal yang negatif. Tetapi harus mampu memanfaatkan teknologi itu dengan benar,sehinga dalam pemanfaatannya pun benar-benar terkendali.

Dalam dunia pendidikan,penggunaan teknologi di bidang internet banyak dimanfaatkan dalam kegiatan pembelajaran. Seperti dimanfaatkan untuk mencari bahan ajar,digunakan sebagai media pembelajaran,sebagai media dalam mengirim tugas,forum diskusi,dan lain sebagainya. Dikarenakan internet mampu mengkomunikasikan informasi antar jaringan komputer yang terpisah jarak dan waktu,sering pula dimanfaatkan dalam kegiatan belajar jarak jauh, oleh sebab itu seorang pendidik,guru,dosen harus mampu untuk menggunakan berbagai macam media dan mengkombinasinya untuk mendukung tujuan pembelajaran. Dalam internet banyak fasilitas yang dapat digunakan sebagai sarana pembelajaran,seperti: Whatsapp,Website,Blog,Facebook, Youtube,Instagram dan lain-lain. Maka dari itu dalam penelitian ini akan membahas Peran Media Sosial (WhatsApp) dalam Proses Belajar Online (Daring) Di Kelas Ap.3/4 Jurusan Ilmu Perpustakaan UIN Alauddin Makassar yang dapat digunakan sebagai media belajar dan sarana pembelajaran.

\section{Metodologi}

Menurut David Kline dalam bukunya yang berjudul "Level of Explanation"sebagaimana yang dikutip oleh Syarifuddin bahwa metode penelitian adalah cara ilmiah yang digunakan untuk mengungkap dan menjelaskan variable yang diteliti dengan variable lain Selanjutnya Sugiyono berpendapat bahwa metode penelitian pada dasarnya adalah cara ilmiah untuk mendapatkan data dengan tujuan dan kegunaan yang memiliki ciri keilmuan yang rasional, empiris dan sistematis. Pendekatan penelitian ini, yaitu, deskriptif kualitatif. Metode penelitian pada penelitian ini dalah simak, catat, dan kajian pustaka. Data dan sumber data pada penelitian ini adalah pendapat atau persepsi dari wawancara pada mahasiswa Kelas Ap.3/4 Jurusan Ilmu Perpustakaan, pengumpulan data menggunakan teknik wawancara. Teknik analisis data menggunakan teknik analisis data interaktif.

\section{Hasil Penelitian}

Berdasarkan hasil wawancara yang peneliti lakukan dengan mahasiswa melalui aplikasi daring yaitu untuk mengetahui sejauh mana peran media social dalam proses belajar menggunakan whatsapp. Adapun pernyataan mahasiswa yang peneliti wawancarai yaitu sebagai berikut: 


\section{a. Informan ke-1}

'Peran media Whats App dalam proses belajar online sangat membantu, terlebih lagi aplikasi WhatsApp lebih mudah digunakan serta penggunaan data yang lebih hemat, kecuali mengunduh file, sebenarnya setiap aplikasi belajar memiliki kelebihan dan kekurangan masingmasing, hanya saja saya berada pada pedalaman/pedesaan, sehingga saya lebih efektif jika belajar dengan menggunakan aplikasi WhatsApp yang jaringannya cukup mendukung. Berbeda dengan aplikasi lainnya yang jaringannya harus ekstra terutama aplikasi Zoom yang membutubkan data dan jaringan ekstra."

\section{b. Informan ke-2}

'Whats App termasuk media komunikasi yang paling banyak digunakan sekarang, karena penggunaannya mudah dipahami, juga dapat mengakses maupun mengirim informasi dengan cepat, dan hal tersebut sangat mendukung dalam proses belajar mengajar, dimana mahasiswa tidak kerepotan dalam penggunaannya karena sudah menjadi media komunikasi mereka seharihari. dan kelebihan lain yang menunjang proses belajar mengajar yaitu di Whats App dapat menerima dan mengirim informasi dalam bentuk tulisan, suara, gambar, video maupun file. video file dan suara yang di terima di Whats App dapat tersimpan secara otomatis, cukup dengan mengunduh secara langsung, berbeda dengan aplikasi lain terkadang ada perintah selanjutnya sampai file tersebut dapat tersimpan dan di akses, Whats App juga mudah dalam menjagkau jaringan, serta hemat dalam penggunaan kuota, selain itu di Whats App dapat kita hapus chat-chat tidak berguna yang masuke dan hanya menyisakan chat yang berguna."

c. Informan ke-3

'Penggunaan Whats App sebagai wadah untuk belajar online merupakan salah satu bentuk apresiasi mahasiswa dalam memanfaatkan aplikasi ini untuk menimba ilmu. Mayoritas mahasiswa Indonesia, khususnya mahasiswa UIN Alauddin Makassar menggunakan aplikasi ini, sehingga memudabkan komunikasi antar pelajar dan pengajar. Whats App yang mudah diakses oleh semua mahasiswa menjadi hal menguntungkan dari berbagai pihak. Apalagi Whats App bisa meng-upload file, video, teks, dan picture. Semua itu sangat membantu dalam proses belajar-mengajar. Tapi, Whats App memiliki fitur video call yang terbatas (biasa hanya untuk 6-8 orang saja), menyebabkan pengajar tidak bisa menyampaikan materi secara langsung (walau virtual). Sepanjang satu semester kami (Ap 3 dan 4) lalui belajar online bisa berjalan dengan baik. Sengaja kami memilih aplikasi whatsapp sebagai alat untuk belajar karena mudah untuk diakses. Penggunaan kuota yang irit pun tidak memberatkan dalam proses belajar. Biasanya kendala dalam kuliah online itu salah satunya adalah jaringan yang buruk. Tapi, penggunaan aplikasi Whats App cukup bisa ditangani."

\section{d. Informan ke-4}

"Sangat membantu dalam hal pembelajaran karena meski tidak memiliki paket data dan hanya bermodalkan gratisan Whats App kita tetap dapat belajar dan menghadiri perkuliahan meski tak bertatap muka."

e. Informan ke-5

"Whats App merupakan salah satu aplikasi atau media yang menurut saya cukup efektif dibandingkan dengan aplikasi lain, Kalau aplikasi lain tidak ribet tapi terkadang kapasitas 
untuk menggunakannya itu terbatas salah satunya kayak Zoom. Beberapa kendala yang di kelubkan mahasiswa adalah jaringan untuk sebagian teman-teman yang sulit mendapatkan akses internet dan kapasistas data yang di pake lumayan lebih besar ketimbang Whats App"

f. Informan ke-6

"menurut saya peran Whats App dalam proses kuliah online sangat efektif dan sangat mudah dijangkau apalagi sekarang banyak teman-teman yang tinggal di perkampungan yang sinyalnya kurang mendukung untuk aplikasi lain seperti Zoom. Jadi aplikasi yang paling bagus untuk di masa pandemi ini adalah Whats App".

g. Informan ke-7

"Lumayan memberikan kemudahan dari segi teknis, tapi tidak efisien bagi proses pembelajarannya. Karena ruang lingkup aplikasi Whats App tidak terlalu besar untuk proses belajar mengajar,baik dari segi kapasitas, kuantitas,dan kualitasnya. Sebab belajar melalui text saja tidak cukup,karena pada dasarnya kita terbiasa dengan pembelajaran secara audio visual."

h. Informan ke-8

"Menurut saya menggunakan aplikasi WhatsApp tentunya memiliki kelebihan dan kekurangan, kelebihan WhatsApp proses belajar cukup mudah karena dapat di akses oleh semua kalangan mahasiswa baik yang diperkotaan maupun yang berada pada pedesaan, serta penggunaan kouta yang lebih hemat. Sedangkan kekuranganya ialah tidak bisa digunakan untuk belajar dengan bertatap muka karena untuk melakukan vc pada Whats App dibatasi hanya dengan delapan orang saja."

i. Informan ke-9

"Menurut saya membantu karena masih bisa berinteraksi degan baik walaupun hanya lewat media chat (text) tapi setidaknya membantu."

j. Informan ke-10

'Penggunaan Whats App dalam perkuliahan dapat membantu proses komunikasi. Mahasiswa tidak hanya terbatas belajar dikelas dan dalam waktu tertentu. Mahasiswa dapat berkomunikasi lebih mudah dengan dosen untuk. bertanya maupun berdikusi baik secara umum di grup kelas maupun dengan dosen secara pribadi."

\section{Diskusi dan Kesimpulan}

\section{Bagaimana Peran Media Sosial (Whatssapp) dalam Proses Belajar Online (Daring) di Kelas Ap.3/4 Jurusan Ilmu Perpustakaan UIN Alauddin Makassar?}

Secara umum peran media sosial (Whats $A p p$ ) sangat baik. Hal ini di buktikan dari hasil wawancara (online) yang dilakukan oleh peneliti,bahwasanya peran media sosial (Whats $A p p$ ) menunjang proses belajar mengajar yaitu di Whats $A p p$ dapat menerima dan mengirim informasi dalam bentuk tulisan, suara, gambar, video maupun file. video file dan suara yang di terima di Whats App dapat tersimpan secara otomatis, cukup dengan mengunduh secara langsung, berbeda dengan aplikasi lain terkadang ada perintah selanjutnya sampai file tersebut dapat 
tersimpan dan di akses, Whats App juga mudah dalam menjagkau jaringan, serta hemat dalam penggunaan kuota, selain itu di Whats $A p p$ dapat kita hapus chat-chat tidak berguna yang masuk dan hanya menyisakan chat yang berguna.

Perkembangan teknologi semakin canggih. Dari tahun ke tahun, temuan hasil karya-karya yang inovatif semakin memudahkan pekerjaan manusia. Teknologi tersebut sangat memudahkan manusia, terutama dalam hal berkomunikasi. Fenomena chatting, Videocall, Comment, Update status, yang selalu melekat di kehidupan sehari-hari seolah olah sangat penting. Setiap mahasiswa di lingkungan kampus selalu dominan membawa gadget dimanapun mereka berada. Para mahasiswa mengungkapkan bahwa media sosial merupakan bagian dari kecanggihan teknologi yang tidak dapat terpisahkan dari kehidupan sehari-hari yang mereka lakukan. Media sosial juga dipergunakan untuk mencari sarana hiburan misalnya bermain game atau menyalurkan hobi seperti fotografi atau minat seputar gadget terkini. Masa pencarian identitas diri mahasiswa tidak terlepas dari gaya hidup yang dikembangkan masyarakat terutama dalam mengisi waktu luang, misalnya yang dilakukan para remaja untuk mengakses media sosial. Sebagai contohnya adalah WhatsApp atau Facebook. Situs pertemanan ini bisa membawa pengaruh negatif jika tidak menyikapinya dengan benar. Individu memiliki sifat dinamis memiliki kecenderungan untuk selalu mengembangkan penemuan baru khususnya dalam bidang ilmu pengetahuan maupun teknologi. Perkembangan media rekreasi saat ini sudah beralih kepada teknologi elektronik yang menjadi bagian terpenting dalam kehidupan sosial masyarakat perkotaan. Penggunaan teknologi media sosial sebagai alat komunikasi maupun hiburan di kalangan mahasiswa perkotaan merupakan bagian dari gambaran tindakan yang dilakukan oleh seorang individu.

\section{Manfaat Media Sosial (Whatsapp) dalam Proses Belajar Online (Daring) Di Kelas Ap.3/4 Jurusan Ilmu Perpustakaan UIN Alauddin Makassar}

Dari hasil wawancara manfaat Whats $A p p$ dalam perkuliahan dapat membantu proses komunikasi. Mahasiswa tidak hanya terbatas belajar dikelas dan dalam waktu tertentu. Mahasiswa dapat berkomunikasi lebih mudah dengan dosen untuk bertanya maupun berdikusi baik secara umum di grup kelas maupun dengan dosen secara pribadi. Ada beberapa manfaat Whats $A p p$ yaitu:

\section{a. Penggunaan WhatsApp sebagai Media Literasi Digital}

Berbagi materi pelajaran (menggunakan fitur Forward) Whats $A p p$ memiliki fitur yang bisa menyimpan dokumen dalam bentuk pdf, microsoft word, excel, dan powerpoint. Maka dari itu, apabila menggunakan Whats $A p p$ berbagi dokumen dengan dengan format bentuk di atas jauh lebih mudah. Selain bisa digunakan menyimpan dokumen dengan bentuk atau format di atas, WhatsApp juga bisa meneruskan pesan, sehingga memudahkan apabila siswa ingin berbagi dengan teman yang lain. Contoh penerapannya adalah ketika seorang mahasiswa memiki materi yang sudah dirangkum atau dicatat ketika di kampus atau dirumah, apabila ada teman yang membutuhkan karena catatannya belum lengkap, bisa dibagikan kepada teman- 
teman yang lain menggunakan fitur forward. Fitur forward memudahkan untuk mengirim atau melanjutkan ke teman yang lain, tanpa harus membuka pada manajer file di gawai.

\section{b. Pembelajaran Jarak Jauh (PJJ)(Menggunakan fitur voice note atau video call)}

Pembelajaran Jarak Jauh (PJJ) bisa dilakukan oleh mahasiswa dan dosen yang tergabung dalam satu grup tertentu. Whats $A p p$ digunakan sebagai media untuk berdiskusi. Awalnya dosen memberikan materi kepada para mahasiswanya yang ada di grup tersebut, kemudian dosen memberikan instruksi untuk mengerjakan soal atau pendapat mengenai materi tersebut. Ketika mahasiswa mengemukakan gagasan atau pendapatnya, harus disertai dengan nama dan kelasnya supaya dosen bisa memberikan penilaian kepada seluruh mahasiswa yang berpartisipasi di dalam grup secara langsung. Dosen harus lebih kreatif dan mengembangkan materi ajarnya yangdiberikankepada mahasiswa,misalnya apabila diskusi,mahasiswa bisa mengemukakan pendapatnya melalui voice note. Selain itu Whats App juga dapat digunakan untuk ujian proposal skripsi,ujian konferen dan ujian munaqasah dengan menggunakan video call.

\section{c. Berbagi Materi melalui Whatsapp Story}

Whats App memungkinkan mahasiswa untuk bisa membagikan materi melalui status,mahasiswa bisa membagikan materi pelajaran atau pengetahuan yang lain dengan menggunakan fitur diWhatsApp, yaitu, WhatsApp Story atau status di Whats App. mahasiswa bisa berbagi foto,video, atau link website menggunakan status.

\section{Daftar Pustaka}

Ellys Lestari Pambayun. 2012. Communication Quotient Kecerdasan Komunikasi Dalam Pendekatan Emosional Dan Spiritual. Bandung: Remaja Rosdakarya. https://inet.detik.com/cyberlife/d-2233962/peran-media-sosial-dalam-

pendidikan. Di akses pada tanggal 2020

Kurniali,S.2009. Peran Media Sosial di Ineternet Pada Penerapan Proses Knowledge Management. Graduate Program in Information System Management BINUS. Vol 1 No $2: 5$

Mulawarman, M.,\& Nurfitri, A. D. 2017. Perilaku Pengguna Media Sosial beserta Implikasinya Ditinjau dari Perspektif Psikologi Sosial Terapan. Buletin Psikologi, 25(1),36-44.https://doi.org/10.22146/buletinpsikologi.22759.

Qomariyah, A.N. 2009. Perilaku Penggunaan Internet pada Kalangan Remaja di Perkotaan. Jurnal Ilmu Sosial. Vol 2 No $2: 1$

Sugiyono. 2009. Metode Penelitian Kuantitatif dan Kualitatif. Jakarta: Gramedia Pustaka Utama.

Syarifuddin, 2011. Metode Penelitian Dakwah dan Komunikasi. Cet.II; Ambon Indonesia: Wadakom Smart.

Suryadi, E., Ginanjar, M. H., \& Priyatna, M.2018. Penggunaan Sosial Media WhatsApp dan Pengaruhnya terhadap Disiplin Belajar Peserta Didik pada Mata Pelajaran Pendidikan Agama Islam. Jurnal Edukasi Islami Jurnal 
Literatify: Trends in Library Developments (Val. I No.2, 202D)

Pendidikan Islam, 07(1), 1-22. https://doi.org/10.30868/EI.V7 